\title{
Belgeo
}

Revue belge de géographie

\section{Territorial government and flexibility: a critical assessment}

Territoriaal bestuur en flexibiliteit: kritische evaluatie

\section{Petr Dostál}

\section{(2) OpenEdition}

\section{Journals}

\section{Electronic version}

URL: http://journals.openedition.org/belgeo/15719

DOI: 10.4000/belgeo.15719

ISSN: 2294-9135

\section{Publisher:}

National Committee of Geography of Belgium, Société Royale Belge de Géographie

\section{Printed version}

Date of publication: 30 September 2002

Number of pages: 227-242

ISSN: 1377-2368

\section{Electronic reference}

Petr Dostál, «Territorial government and flexibility: a critical assessment », Belgeo [Online], 3| 2002,

Online since 01 October 2002, connection on 20 April 2019. URL : http://journals.openedition.org/ belgeo/15719; DOI : 10.4000/belgeo.15719

This text was automatically generated on 20 April 2019.

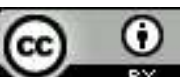

Belgeo est mis à disposition selon les termes de la licence Creative Commons Attribution 4.0 International. 


\title{
Territorial government and flexibility: a critical assessment
}

\author{
Territoriaal bestuur en flexibiliteit: kritische evaluatie
}

Petr Dostál

This research was supported by grant MSM 113100007

«Change requires flexible institutions, capable of adjustment without disruption. But change also requires a prospect, a design into the future, an idea of where one might go. Such ideas are provided by those engaged in representative activities... Without the emergence of new ideas by representative activities, societies become truly hopeless, drab, grey and profoundly miserable.»

(Dahrendorf, 1979, p. 163).

\section{Introduction}

1 This paper examines the character of multipurpose territorial government and explores the meaning of frequent calls for more flexibility in the structures and functioning of local and regional governments. Living in a world of multiple identities and authorities and associated external pressures for change and adjustment-a circumstance often mistakenly referred to as postmodernity-is a challenge to the effectiveness of local and regional multipurpose governments. In the modern societies of the late nineteenth century and most of the twentieth century, public interest articulation in the structure and function of local and regional governments has always been under pressure from the diverse interests of a variety of internal and external actors, be these individual citizens or corporate actors such as firms or political parties. Thus, it is hardly surprising that the calls for responsiveness of local and regional government to changing economic, societal and environmental circumstances and to the associated diverse interests of various actors have roots stretching back to the formative period of multipurpose territorial government in the nineteenth century. This was the time when John Stuart Mill wrote his "Considerations on Representative Government», published in 1861, in which he strongly advocated the establishment of local representative bodies. However, the two quotations 
above, taken from the liberal formulations of David Harvey (1971) and Ralf Dahrendorf (1979), clearly indicate that, at least since the 1970s, the calls for more flexibility on the part of representative multipurpose governments, and so greater capacity to adjust to internal and external pressures without disruption of their public integrative tasks, have become important in debates on changing local and regional government. Such frequent calls for more flexibility and adjustment are not accidental (see for example WRR, 1998; Rhodes, 1997; King and Stoker, 1996). Continuing debate on the difficult tasks of territorial governments, to articulate and represent general public interests, have emphasised the need for creative design of public policies and their more effective implementation in circumstances of emerging largely globalised hypermodern society (see also Bennett, 1997). Further, the debate has rightly been concerned with fragmentation and unanticipated impacts of increasing territorial complexities in areas of public administration and self-government. Increasing territorial complexities have resulted from decisions taken on locations, spatial overspill effects and changing spatial relationships, caused by a wide range of private and public actors-i.e., by «the tyranny of small decisions» (Kahn, 1976). Firstly, in accordance with Harvey (1971), I have to emphasise the crucial point that location decisions and positive or negative spatial overspill effects have had important redistributive effects on locally and regionally bounded welfare situations and the life chances of citizens (see also Hägerstrand, 1976; Hägerstrand and Clark, 1998). Spatial overspill effects are difficult to forecast, and it seems that a need arises for flexibility in the structure or functioning of local and regional governments. Secondly, with Dahrendorf (1979), I have to stress the importance of flexible adjustment capability and creative, future-orientated decision-making on the part of representative multipurpose governments. Their integrative tasks are needed for effective responses to external and internal pressures on the territorially bounded welfare situations of their citizens (see also Dostál and Hampl, 1999; Dostál and Saey, 2000). Wider ranges of competencies of local and regional governments seem to allow more flexible decision-making. Therefore, it seems worthwhile to explore the meaning of the concept of flexibility in order to assess its possible usefulness in solutions of emerging issues of responsiveness, functioning and structural problems of multipurpose territorial governments.

2 The paper is organised as follows. First, I will elaborate on a number of starting points of debates concerned with the shift from territorial government to territorial governance. Second, I will elaborate on the notion of flexibility. I will argue that the need for flexible system capability at local and regional levels of multipurpose government is linked primarily to external uncertainty in the environment in which local and regional governments have to operate. Third, I will point to the importance of the indispensable integrative character of the territorial competence of local and regional multipurpose self-governments. Finally, building on this, I will emphasise the issue of public interest formation and aggregation, and adverse impacts of fragmentation on the integrative territorial competence of multipurpose governments.

\section{Starting points}

3 At least since the 1970s, external and internal pressures have been leading to a decreasing integrative territorial competence of multipurpose governments at local and regional levels. Multipurpose (or general purpose) governments have integrative competence, 
over a wide range of tasks, that allows a significant level of self-governmental discretion in respect of priorities to be established between various tasks (such as education, housing and roads). Their territorial competence has been weakened through everincreasing complexity and associated uncertainty about future territorial changes in economic, social and environmental conditions, and spatial relationships and uncertainties about their unequal impacts on the life chance of citizens and societal groups (Hägerstrand, 1973; Törnqvist, 1983; Dostál, 1984, pp. 27-35). In consequence, the issue of the weakening of their integrative territorial competence has been felt particularly in respect of the structure and functioning of multipurpose territorial government and, obviously, much less where single-purpose territorial administrations are concerned. In current hypermodern society, the various pressures on multipurpose territorial governments have led to considerable adaptations or reforms of (i) their ways of functioning, (ii) often, also, their institutional structures and competencies, and (iii) sometimes, their territorial structures. Hypermodern society refers to currently highly intensified modern society with its accelerated developments in technical and economic realms, which are feeding and increasing contingency in spatial dimensions (such as those concerning transportation and communication) and along the temporal axis (such as faster globalisation of the banking system). Significantly, hypermodern society also refers to an intensified decline in traditional privileges and the compromises of post-war modern society, such as welfare state commitments. There is also an institutional fragmentation and the recoupling of corporate actors in relation to other economic and political organisational systems, carried on by intensified specialisation and functional differentiation (see also Offe, 1996).

4 It is conventional wisdom to associate many of the recent adaptations of multipurpose government with the shift of territorial government to territorial governance (cf. for instance, Goodwin and Painter, 1996; Rhodes, 1997; Barlow, 1998; Goldsmith, 2001). In order to assess the shift towards territorial governance, the following points have to be highlighted.

1. The former uniform systems of local or regional multipurpose governments (i.e., municipalities or provinces) have been transformed into more diversified and complex systems of local or regional governance, involving actors drawn from the public, private and voluntary sectors. Consequently, it must be noted that the concept of territorial governance is thus more comprehensive in terms of the numbers and characters of the actors involved than that of territorial government.

2. The shift towards territorial governance seems to be marked by increased institutional fragmentation and a decline in local and regional government influence in their respective areas (i.e., a decline in the influence of the actors in the self-governmental sector). According to Goldsmith, «governmental responsibilities in such areas are shared between a wide range of public bodies, some elected, many appointed, and where cooperation with the private sector is often a requirement of successful policy implementation.» (2001, p. 325). Boundaries between public, private and voluntary actors changed and became less transparent. Elected local and regional multipurpose governments are still seen in the context of democratic regimes as key political institutions. However, in the configuration of territorial governance, they are thus operating within a broader and more diverse range of actors at local and regional levels, such as non-elected agencies of the state, private businesses, voluntary organisations, the mass media, and EU institutions.

3. This means also that the relevant operational environment of multipurpose territorial governments, with their crucial integrative tasks, has become more complex and inevitably associated with more uncertainty about the formation of special interests and the behaviour 
of those corporate actors involved (Rhodes, 1997, pp. 53ff). The shift to territorial governance means that there emerge important degrees of autonomy of the actors from the state because governance networks are less accountable to local and regional multipurpose governments. Situations of diffused accountability arise from continuing interactions between network partners, exchange of resources and negotiation of shared purposes. In consequence, there are good reasons to ask how democratic accountability can be maintained.

4. Significant shifts in policy-making have taken place, resulting in more entrepreneurial responses from local and regional governments. They have adopted more flexible procedural styles, task-oriented models and modes of implementation, using various proactive and innovative institutional, problem-oriented and territorial modalities to go beyond the rigidities of the traditional approaches used by the multipurpose territorial government (see also Imrie and Raco, 1999; Bennett and Krebs, 1994; Bennett and Payne, 2000; Rhodes, 1997; WRR, 1998; Valler, Wood and North, 2000). Importantly, one of the key characteristics of such a shift from government to governance is claimed to be increasing flexibility and responsiveness, in both the functioning and structure of territorial government. It is clear from the debates on the transformation of territorial government to governance that the notion of flexibility belongs to the popular vocabulary of our hypermodern era, with its great emphasis on flexible capacities of local and regional authorities. The notion of flexibility seems to have a mobilising value that supports the efforts of local and regional authorities to maintain and strengthen their territorial competence.

5 In an earlier comment on the need for more flexibility in territorial administration, Bennett provided some other starting points for further critical assessment of the concept of flexibility. He made a distinction between vertical and horizontal dimensions. Considering vertical relations-i.e., those between the central, regional and local tiers of government-he argued that «flexible decentralisation ... is the means of achieving a close relation of services and satisfaction of needs to local preferences and community requirements, as well as assuring a high level of participation and representation.» (1989a, p. 6). In respect of horizontal dimensions at specific tiers of the governmental structure, he claimed that «flexible aggregation of different sizes of units is the only means of maintaining an adaptable but stable financial and administrative structure. This leads to arguments for different mixes of co-ordination, agency arrangements, 'associations' of local administrative units and different mixes of public administration, public finance and (market) responses.» (1989a, p. 7). Elaborating on a possible future research agenda, Bennett maintained this twofold approach. He suggested that there is a need for «flexible decentralisation to the most basic and smallest units where the demand for participation, legitimacy, representation and community identity can be met; and flexible aggregation of basic units into collectives, co-operatives and associations for which efficient sizes of administration can be achieved which allow internalisation of externalities and technical-bureaucratic efficiency». On the other hand, he must draw the conclusion that «[t]his suggestion, however, opens more questions than it answers» (1989b, p. 303). Even today, more than one decade later, one must accept that the calls for more flexibility in the systems of multipurpose territorial government are raising more questions than indicating possible answers. Particularly in connection with the shift from territorial government to territorial governance, the question arises whether (i) increased flexibility would demand far-reaching structural changes or whether (ii) it seems more appropriate to change only the ways or styles in which territorial selfgovernmental systems function. Structural changes would imply adaptation of 
institutional arrangements, competencies and changes in the number of tiers and/or in the number and delineation of territories of local and regional multipurpose governments. It seems that the 1989 calls of Bennett for flexible decentralisation and flexible aggregation referred especially to the need for structural adaptations: (a) institutional changes (i.e., decentralisation reforms) and (b) territorial changes (i.e., reforms in the number of tiers and in the number and sizes of territories). In contrast, non-structural adaptations would result in changes in (c) functioning that would necessitate only limited adaptations to external and internal pressures, thus implying less far-reaching and more flexible adaptations in approach, procedures and style.

The calls of Bennett (1989a; 1989b) for more flexible decentralisation and flexible aggregation are thus primarily concerned with far-reaching reforms of local and regional government aiming at optimum government structures, and less with flexible adaptations in approach, style and procedure. Drawing upon the issues of territorial governance indicated above, it is therefore worthwhile to discuss an approach to the notion of flexibility that can enhance the territorial competence of local and regional governments. The concept of territorial competence refers to the effective capacity and activities of local and regional governments in relation to their calling-i.e., to satisfy the requirements of democratic multipurpose governmental authorities within the domains of their self-governmental territories. This does not necessarily mean that the selfgovernmental authorities can and must control everything inside their territories. However, the complexities of external and internal pressures on self-governmental territories and the increasing importance of systems of local and regional governance focused on single purpose projects have had significant fragmenting impacts on the necessarily integrative nature of public interest articulation in democratic governments. This fragmentation and the ever-increasing complexity and associated uncertainty about future territorial changes in economic, social and environmental conditions and spatial relationships, and uncertainty about impacts of public policies, seem to tend towards a decrease in the territorial competence of local and regional governments. When it comes to strengthening the territorial competence of local and regional multipurpose governments, however, the concept of flexibility should not be uncritically accepted.

\section{Flexibility: responding to uncertainty}

7 In discussions on territorial governance, the concept of flexibility is usually associated with almost any change in structure and/or functioning of the local and regional government. Therefore, it is necessary to provide greater conceptual clarity of the notion and to re-assess some basic conceptual principles that underlie the notion of flexibility in relation to the structure and functioning of territorial self-government and its administration.

Flexibility is a future-oriented notion. Flexibility relates to the wish to keep open the present situation in view of coming future situations. It is, however, also clear that the notion of flexibility is an instrumental concept. In consequence, it cannot be an important goal of reforms, because it can only be used as a tool. Moreover, it is appropriate to recognise that flexibility is a notion having various connotations. It is too often used in debates on governance as a catch-all notion. From a more analytical 
viewpoint, flexibility appears to refer to shifting the function of administrative systems along the following dimensions:

- from uniformity to pluriformity,

- from permanency to variability,

- from rigidity towards readiness for action, or

- from detailed stipulations and regulations towards general delineation.

Thus, it appears that flexibility refers to the capability of organisational systems to react quickly to ongoing variety or uncertainty in the environment by adapting their functioning and some structural features along the four basic dimensions (Dostál et al., 1988, pp. 5-9). Accordingly, the conclusion to be drawn is that the concept of flexibility refers to the ability of organisations and their principal decision-makers to operate rapidly in an environment that is characteristically fast-changing and very difficult to comprehend (i.e., to forecast). Such environments are difficult to control effectively in circumstances of considerable uncertainty (cf. Kickert, 1982; 1986; van Gunsteren, 1976). The specification of the four dimensions indicates that flexibility concerns the subjective attitudes of decision-makers and their willingness to think and act in terms of more alternatives, as well as in terms of alternative objectives of societal institutions and rules and organisational systems.

The notion of flexibility is thus cognate with some other notions that are popular todayderegulation, privatisation, commercialisation, outsourcing, etc. It is a member of the family of words that we use today in order to underline the need for putting «in motion» various rigidly institutionalised relationships and connections. Yet, the question arises on what such a «motion» must be focused and, importantly, to what purposes it can be employed. The definition provided above makes clear that flexibility refers to the ability of administrations and their principal decision-makers to operate in an environment that is characteristically fast-changing and also difficult to understand; to anticipate; and, consequently, to control effectively. Considering the meaning of flexibility in governmental and administrative systems, it is important to emphasise that flexibility does not only imply the use of steering rules from the existing arsenal of institutional restrictions, laws and organisational principles (cf. Kickert, 1982, pp. 486ff). Instead, in flexible operations, actors seek the extension of management variety. This implies that flexible management is based on the capacity to enlarge the existing arsenal of governmental and administrative devices. It is in this sense that increasing flexibility in the functioning of multipurpose governments can enhance their territorial competence. The shift from territorial government towards territorial governance indicates that the need for flexible system capability at local and regional levels of multipurpose governments is primarily connected with pressures of external uncertainty in their operating environments (cf. Imrie and Raco, 1999). It seems that, in particular, organisational devices of flexible decentralisation (or centralisation) along the vertical dimension of self-governmental and administrative systems (devolution of competencies to regional and local tiers) as emphasised by Bennett (1989a; 1989b), can contribute significantly to increasing the arsenal of institutional modalities. In addition, new territorial modalities will have to be sought along horizontal dimensions of flexible aggregation involving ways of inter-unit co-operation, association, and pooling of resources and administrative capacities in order to adapt to the emerging uncertainties of internalisation of externalities and uncertain changing conditions of technical and bureaucratic efficiency and indivisibilities in public service provision. 
11 The introduction of more flexibility in territorial self-government and administration is often understood as associated with the abolition of existing institutional structures and ways of functioning. It is important to note that this lacks validity because many so-called «obsolete» institutional structures or rules and organisational devices must still be used by the multipurpose government in order to maintain territorial competence in traditional and more predictable sections of the current hypermodern and increasingly more complex environment. Uncritical use of the concept of flexibility can result in considerable conceptual confusion, especially when the notion of flexibility is equated to change. The meaning of the concept of flexibility has often been «hollowed out» by uncritical over-stretching of the meaningful content of the concept. Indeed, the notion of flexibility has been used too often in a way that has been equated with the unspecified general meaning of «change». However, from the short discussion of this section, it appears that the concept of flexibility can be given (in the field of administrative geography) a specific and more useful meaning. The frequent calls for increasing flexibility are overstated if its specific meaning is stretched too far. It is important to note that flexibility implies, among other things, continuing use of existing institutional rules and structures. Further, in administrative geography, flexibility refers to the subjective attitudes of the decision-makers and their actions as well as to adaptations of institutional rules. The capability of flexible decision-making is based on the attitudes of people who are ready to take future-oriented steps while considering current rules and structures, alternatives and non-traditional solutions, thereby better matching the emerging variety in the relevant dynamic environment and responding to uncertainty. Here, one can quote Nelson and Winter (1982, pp. 383-384): «the flexibility of an action today, in terms of the range of choice kept open for tomorrow, and the information about alternative futures paths that action will create, are important desiderata. At best, strategic road maps are grossly drawn.» In a similar way, Scott (1987) claims that these insights are challenging the popular and wide-spread assumption that some generally applicable organisational principles can be developed that can be suitable in all places and times. Accordingly, this elaboration on the notion of flexibility suggests that we seemingly have to accept the following three propositions: (i) there is no generally best way to organise flexibly, (ii) various ways of organising flexibility are not equally effective and efficient, and (iii) the best way to organise flexibly is always dependant on the character of the relevant environment to which the organisation must be related, given its tasks and ambitions or obligations. In short, this basic ecological reasoning on the meaning of flexibility claims that those organisations whose internal features best match the circumstances of their environment and whose principal decision-makers anticipate future changes and increased variety of available organisational tools will achieve the best adaptation, as indicated by their performances (cf. also Mintzberg, 1983, pp. 143ff).

In sum, in the field of territorial government, the concept of flexibility refers to the capability of local and regional governments to react rapidly to change, fragmentation and resulting uncertainty in the environment, and thereby to enhance their territorial competence. However, it also seems that the flexibility thesis is often overstated, because a tension emerges between, on the one hand, the pressures for increased flexibility of governmental systems leading to the far-reaching shifts towards governance and, on the other hand, the crucial integrative tasks of multipurpose territorial governments that have to provide for necessary continuity and stability also in arenas of current local and regional politics and maintain democratic accountability. 


\section{Multipurpose government: the integrative nature of territorial competence}

13 Since Mill's «Considerations on Representative Government», a series of normative arguments and conceptual principles in favour of local (and regional) government have strongly influenced debates on territorial administration in various European countries (Bennett, 1992; 1993). Going further than utilitarian norms of central state supervision and efficiency of administration, Mill's work emphasised (i) the importance of a systematic hierarchy of administrative bodies and (ii) the need for local (and regional) institutions to establish and maintain enough territorial competence within the jurisdictions concerned. At least since that time, traditional conceptualisations concerning territorial government in democratising countries were based on two major principles. First, there was the view that local (and regional) self-governmental institutions have to be part of any democratic regime in order to provide for participation and education of citizens in political decision-making and governing. Second, there is the supplementary view, which stresses the importance of wide ranging competencies on the part of local (and regional) self-government based on a multifunctional package of skills that guarantee the provision of services efficiently and effectively owing to local/regional knowledge and interest articulations and an ability to oversee local or regional affairs (cf. also Stoker, 1996). This twofold conceptualisation gave politicians and scholars a comprehensive perspective of a hierarchy of relatively autonomous, multipurpose governmental bodies providing public services, having the capacity to raise local or regional taxes and regulated democratically by elected representatives overseeing the functioning of full-time professionals (see also Dahl, 1990).

Rational-functional and normative approaches dominated ongoing debates on the need for the reform of multipurpose governments in the 1970s and 1980s. As Leemans (1970) and later also Sharpe (1993) made sufficiently plain, there were major concerns during the 1970s and 1980s over a rational-functional set of factors. This set of factors was basically connected with issues of rationalisation having to do with social, economic and ecological interdependencies and pressures and leading largely to scale-enlargement of local, and often regional, units of self-government and administration in order to cope with the impacts of urbanisation and suburbanisation and new responsibilities for the provision of public services (see also Blaas and Dostál, 1989; Barlow, 1998 on the case of the Netherlands). Later, the importance of the impacts of internationalisation and globalisation was also taken into account (cf. for example de Smidt, 1990; Barlow, 1993). On the other hand, however, there were also concerns with normative issues of democratisation (cf. Leemans, 1970; Sharpe, 1979; Bennett, 1989). There is little need to re-examine here the wide range of democratisation and rationalisation issues discussed in the 1970s and 1980s, because these have been examined extensively in the relevant literature. However, from the perspective of an increasing need for flexibility of territorial government, the democratisation issue concerned with the integrative character of political decision-making in the multipurpose governments, as well as the rationalisation issue of territorial effectiveness of internalisation of external effects within one jurisdiction, still deserve a more detailed examination (cf. also Dostál and Hampl, 1999; Dostál and Saey, 2000). 
15 It is clear that, from Mill onwards, advocates of traditional conceptualisations of the multipurpose local or regional representative government have shared a common underlying understanding. It is the principle of the sufficiently integrative nature of political decision-making at each self-governmental tier. This principle particularly implies a wide range of competencies and means in fields of political decision-making that mutually communicate with each other in terms of policy substance and measures. In brief, this principle warns against adaptations of the multipurpose government tending to fragment the capacity of comprehensive political decision-making. Fragmentation necessarily results from functional (or single-purpose oriented) solutions of decentralisation of competencies in the self-government and from the splitting of scarce means in the dispersed state administration by separate sectors (for recent discussions of single-purpose governance and partnership systems, see Rhodes, 1997; Elander, 2002). It is important to note that fragmentation of decision-making in local/ regional democratic bodies and dispersed state agencies tends to compel actors to interact more along vertical lines with actors in the same policy sector at national level. In consequence, horizontal interactions in the policy-making are constrained, and the integrative character of the territorial competence of the multipurpose government is weakened. The point to be highlighted here is that this emphasis given to single purpose interactions usually implies too much importance given to the segmented (i.e., partial or one-sided) views of interest articulations and interest aggregations of actors in one sector (cf. also Törnqvist, 1980; Hägerstrand and Clark, 1998). Accordingly, the following two crucial points have to be emphasised. First, a sufficiently wide range of competencies allows (i) multidirectional co-ordination of public service provision and (ii) room for balancing of competing priorities and (iii) checking on the segmented power of organised partial interests of separate sectors (see also Dostál, 1984, pp. 29-35; Dostál and Hampl, 1999). Therefore, already at this stage of the discussion, one can draw the important conclusion that a wide range of competencies allows more flexible policy-making. Second, there is also another crucial point to be mentioned in this context. The multipurpose character and consequent wide range of competencies of local/regional self-governments is needed for revealing and reconciling preferences and also for stimulation of deliberative capacity at local and regional levels of the political system.

These are key claims of the arguments in this paper. Thus, a wide range of competencies is necessary when current local and regional governments are expected to play an important role in bringing individual segments of the policy-making together. Only a wide range of competencies can provide sufficient decision-making capacity, which is particularly important given the increasing uncertainty and spillover effects of many of the issues confronting local and regional areas in the era of hypermodernity. It must also be noted that social and economic pressures for democratisation and rationalisation interact (Dostál and Saey, 2000). In consequence, the issue of the integrative character of self-governmental policy-making is linked with the issue of territorial effectiveness of internalising important external or spillover effects within appropriate territorial jurisdictions. There is, thus, a tension between current shifts towards territorial governance, on the one hand, and the continuing need for the integrated character of the tasks of the multipurpose self-government and its territorial competence, on the other hand. The tension is there, because local and regional governance implies a wider range of actors reaching beyond the arena of the territorial multipurpose governments and including a variety of institutional and individual actors: voluntary and private and 
public sector actors with different interest articulations all involved in regulating a local/ regional economy and society (Imrie and Raco, 1999; Johnston and Pattie, 1996; Barlow, 1998; WRR, 1998; Elander, 2002). In consequence, the shift to governance usually implies that the integrative tasks of multipurpose territorial government tend to dissolve and fragment into a considerable number of single-purpose agencies, some of them externalised and privatised or in the form of public-private partnerships, non-elected organisations and voluntary agencies. Accordingly, there arise issues of public interest aggregation and fragmentation that have pertinent relevance in any critical assessment of the calls for flexibility.

\section{The issue of interest formation and fragmentation}

17 With Scharpf (1997, 61-66), I make a distinction between (self-)interest and identity in order to show basic differences between partial interest formation and integrative/ complex interest formation because the preceding discussion shows that the institutional (self-)interest of local and regional governments as corporate actors must be granted a special place in debates on the need for flexibility. Self-interest describes the basic preference of actors for self-preservation, autonomy and growth. For individual citizens, the operative implications relate to the Weberian normative orientation of well-being, income, influence and social recognition or prestige. Similarly, for corporate actors such as enterprises, political parties, employment offices and provincial governments, basic self-interest is defined by the conditions of their organisational autonomy, survival and growth. It is obvious that the conditions depend on the institutional environment within which the various corporate actors have to operate. What matters here is that individual, organisational and self-governmental interests have different normative and strategic implications. Firms and similar private organisations follow less integrative and less complex courses in their formation of interest because they are created and maintained to serve specific partial purposes. This is indicated in their one-sided («simple») missions and basic organisational goals. For example, Elander, assessing public-private partnerships as a frequent organisational form of urban governance, argues that "partnerships may legitimise policies that favour actors and interests in society who are already among the winners. In any case, the relationship between partnerships and democracy is a tricky one, which has not, so far, attracted due interest in the public debate or in research.» (2002, p. 202). The point to be emphasised is that interest formation is based on the specific identity of the corporate actors concerned. As Scharpf (1997, p. 65) has noted, «actors have the possibility of defining a specific identity, which, if adhered to, will specify their own choices and which, when communicated and believed, reduces uncertainty for other actors (and for researchers as well).»

The identities of corporate actors must be relatively stable over time in order to be effective and to form a necessarily predictable environment for mutual interaction and functioning. Here, I arrive at a crucial point of the argument. Firstly, the integrative character and complexity of functioning of local or regional multipurpose selfgovernmental units derives from the necessity to (re-)articulate, by democratic procedures, their local and regional identities. Given the heterogeneity of the selfinterests of citizens forming a local or regional electorate, a territorial self-government will always have the crucial general task of aggregating public interests in order to balance and reconcile emerging partial interest formations within the territorial 
jurisdictions concerned. Secondly, the integrative character and complexity of the interest formation of a multipurpose territorial self-government also derives from an increasing comprehensiveness of its co-ordinating function. Owing to increasing complexities of economic, social, political and ecological processes in its territorial domain, the traditional co-ordinating and balancing roles of the multipurpose government become inevitably more complex (Dostál and Hampl, 1999; Dostál and Saey, 2000). Here, I arrive at one of the central conclusions of the paper. It can be claimed that democracy, including territorialised democracy in the form of local or regional selfgovernment, is an integrative affair which has to provide an indispensable co-ordinating, and public interest-articulating and aggregating, framework for the partial and less complex interest formation and behaviour of other corporate actors and individual citizens.

This emphasis given to increasing complexity and the integrative character of the decision-making of multipurpose governments as corporate actors, relates thus to the issues of fragmentation of self-governmental and administrative systems. These issues have been examined in a number of publications (see for example Barlow, 1994). Fragmentation refers to situations where a territory is subdivided into several contiguous governmental sub-territories such as municipalities, districts or provinces. Fragmentation also refers to situations where the functions and competencies of the government of a territory are divided among various single-purpose authorities and agencies. The former case is territorial fragmentation and the latter is functional fragmentation. As I have already emphasised above, the administrators of single-purpose bodies are inclined to function from the perspective of their one-sided (partial) identity and interest formation and lack the integral perspective of a multipurpose selfgovernmental body. It must be noted that a multiplicity of special single-purpose corporate actors is confusing to citizens: lines of accountability are often hidden and decision-making tends to be concealed from democratic control. Consolidation of the various special-purpose actors into an integrative multipurpose territorial selfgovernment is the obvious solution to this fragmentation problem. As Barlow (1994) and many other observers have explained, some functions are of a technical character and may be carried out more effectively outside the more politicised multipurpose government. However, the point to be emphasised in this paper on flexibility is that if reform proposals are carried only on the trend towards local or regional governance and, thus, the integrative character of the decision-making of territorial self-governmental bodies is not recognised, then territorial and functional fragmentation can reinforce each other and create extreme problems in terms of effective size, scarce resources and coordination and capacity for action. Such fragmentation would lead in a cumulative manner to further decreases in the territorial competence of the multipurpose selfgovernment and administration. In sum, weakening or abolition of multipurpose territorial governments does not enhance the flexibility of the systems of selfgovernment and administration.

\section{Conclusion}

One may draw the conclusion that the popular view of flexibility-seeing flexibility as simple change in the structures and/or functioning of the local and regional multipurpose government-is an inadequate conceptualisation. Such a simplified 
conceptualisation of the notion of flexibility is too easily associated with (i) decisions leading to hasty «demolitions» of existing institutional structures and organisational systems, and (ii) with systems of governance favouring actors and interest formations in local and regional society that are already among the winners. Instead, the critical assessment provided in this paper shows that the notion of flexibility appears to refer to the capability to react to unpredictable future developments by enlargement of the management capacity of the multipurpose government with alternative new steering and decision-making rules. Correspondingly, flexibility refers not necessarily to changing existing organisational structures of territorial self-government and administration, but primarily to adaptations of their functioning and therefore to increasing flexibility of rules and approaches. In other words, the notion of flexibility is primarily linked with issues of government strategy and practices and less with those of government structure and form. Fragmentation of local and regional policymaking of multipurpose governments in systems of governance is challenging systems of territorial representative democracy and accountability. Systems of governance cannot replace systems of local and regional government that are accountable to all the citizens of localities and regions who are eligible to vote in free elections. There is a need for governance, for reasons of efficient and effective action, but these reasons must not imply weakening of representative democratic politics. Economic actors operating at the intranational and supranational levels of current hypermodern society are forming a large plurality of actors led by articulation of partial interests. They confront the multipurpose territorial self-government and administration with important pressures for change and for flexible functioning as well as with complexities of their specific decision-making, with uncertainty about their location preferences and associated positive and negative spatial overspill effects on the conditions and decision-making of others. However, it must be recognised that democratic multipurpose governments represent more integrative interest formations. Therefore, it is hardly surprising that territorial governments and administrations, confronting frequent needs for reform and adaptations, appear to possess inbuilt tendencies to become «obsolete». I have to emphasise again that democracy, including territorialised democracy in the form of local and regional multipurpose self-governments, is an integrative affair. Furthermore, current multipurpose self-governments provide, by their territorial competence, indispensable co-ordinating frameworks for partial and less integrative interests formation and behaviour of corporate actors and individual citizens, and they can respond-by the enlargement of the existing arsenal of their competencies and approaches-to current uncertainty in a flexible way, avoiding fragmentation of their integrative co-ordinating role.

\section{BIBLIOGRAPHY}

BARLOW M (1993), «Large city reforms», in BENNETT R.J. (ed.), Local Government in the New Europe, London, Belhaven Press, pp. 130-143. 
BARLOW M. (1994), «Issues and problems of fragmentation in local and regional administration», in BARLOW M., DOSTAL P. and HAMPL M. (eds.), Territory, Society and Administration. The Czech Republic and the Industrial Region of Liberec, Amsterdam, University of Amsterdam, pp. 123-143.

BARLOW M. (1998), Amsterdam and the Question of Metropolitan Government, Amsterdam, University of Amsterdam/AME.

BARLOW M., DOSTÁL P. and HAMPL M. (1994), «Introduction», in BARLOW M., DOSTAL P. and HAMPL M. (eds.), Territory, Society and Administration. The Czech Republic and the Industrial Region of Liberec, Amsterdam, University of Amsterdam, pp. 1-17.

BENNETT R.J. (1989a), «Territory and administration», in BENNETT R.J. (ed.) (1989), Territory and Administration in Europe, London, Pinter, pp. 3-7.

BENNETT R.J. (1989b), «Territory and administration: towards a future research agenda», in BENNETT R.J. (ed.) (1989), Territory and Administration in Europe, London, Pinter, pp. 303-313.

BENNETT R.J. (1992), «European administrative reforms: dimensions for analysis of diversity», in DOSTAL P., ILLNER M., KARA J. and BARLOW M. (eds.), Changing Territorial Administration in Czechoslovakia. International Viewpoints, Amsterdam, Instituut for Sociale Geografie, pp. 139-148.

BENNETT R.J. (ed.) (1993), Local Government in the New Europe, London, Belhaven Press.

BENNETT R.J. (1997), «Administrative systems and economic spaces», Regional Studies, 31, 3, pp. 323-336.

BENNETT R.J. and KREBS G. (1994), «Local economic development partnerships: an analysis of policy networks in EC-LEDA local employment development strategies», Regional Studies, 28, pp. 119-140.

BENNETT R.J. and PAYNE D. (2000), Local and regional economic development, Aldershot, Asgate Press.

BLAAS H. and DOSTÁL P. (1989), «The Netherlands: changing administrative structures», in BENNETT R.J. (ed.), Territory and Administration in Europe, London, Pinter, pp. 230-241.

DAHL R. A. (1990), After the Revolution? Authority in a Good Society. Revised edition, New Haven, Yale University Press.

DAHRENDORF R. (1979), Life Chances. Approaches to Social and Political Theory, London, Weidenfeld and Nicolson.

DOSTÁL P. (1984), «Regional policy and corporate organizational forms: some questions of interregional social justice», in DE SMIDT M. and WEVER E. (eds.), A Profile of Dutch Economic Geography, Assen, Van Gorcum, pp. 12-38.

DOSTÁL P. and HAMPL M. (1999), «Changing local and regional government: issues of democracy, integrality and hierarchies», Acta Universitatis Carolinae - Geographica, 34, 1, pp. 3-18.

DOSTÁL P., MARKUSSE J. and BLAAS H. (1988), Friesland in Perspectief. Hoofdlijnen van een drietal sociaal-ruimtelijke scenarios op middellange termijn, Amsterdam, Provinsje Frysland.

DOSTÁL P. and SAEY P. (2000), «Geography, public administration and governance», The Belgian Journal of Geography, 1, 1-4, pp. 65-78.

ELANDER I. (2002), «Partnerships and urban governance», International Social Science Journal, 172, pp. 191-204.

GOLDSMITH M. (2001), «Urban governance», in PADDISON R. (ed.), Handbook of Urban Studies, London, Sage Publications, pp. 325-335. 
GOODWIN M. and PAINTER J. (1996), «Local governance, the crisis of Fordism and the changing geographies of regulation», Transactions of the Institute of British Geographers NS, 21, pp. 635-648.

HÄGERSTRAND T. (1973), «The domain of human geography», in CHORLEY R.J. (ed.), Directions in Geography, London, Methuen, pp. 67-87.

HÄGERSTRAND T. (1976), «The national settlement pattern as a political problem», in Plan International, pp. 45-56.

HÄGERSTRAND T. and CLARK E. (1998), «On the political geography of transportation and land use policy coordination", in Transport and Land-use Policies: Resistance and Hopes for Cooperation, European Commission, Directorate General Transport, Luxemburg, OOPEC, pp. 19-31.

HARVEY D. (1971), «Social processes, spatial form and the distribution of real income in an urban system», in CHISHOLM M., FREY A.E. and HAGGETT P. (eds.), Regional Forecasting, London, Butterworth, pp. 267-300.

IMRIE R. and RACO M. (1999), «How new is the new local governance? Lessons from the United Kingdom», Transactions of the Institute of British Geographers NS, 24, pp. 45-63.

JOHNSTON R. and PATTIE C. (1996), «Local government in governance: the 1994-95 restructuring of local government in England», International Journal of Urban and Regional Research, 20, 4, pp. 671-696.

KAHN A. (1976), «The tyranny of small decisions: market failures, imperfections, and the limits of economics», Kyklos, 19, pp. 23-47.

KICKERT W. (1982), «Het toverwoord flexibiliteit», Bestuurswetenschappen, 36, 7, pp. 476-495.

KICKERT W. (1986), Overheidsplanning. Theorieen, technieken en beperkingen, Assen, van Gorcum. KING D. and STOKER G. (eds.) (1996), Rethinking Local Democracy, London, Macmillan Press.

LEEMANS A.F. (1970), Changing Pattern of Local Government, The Hague, IULA.

MINTZBERG H. (1983), Structure in Five: Designing Effective Organizations, Englewood Cliffs, NJ, Prentice-Hall.

NELSON R.R. and WINTER S.G. (1982), An Evolutionary Theory of Economic Change, Cambridge, MA, Harvard University Press.

OFFE C. (1996), Modernity and the State. East, West, Cambridge, Polity Press.

RHODES, R.A.W. (1997), Understanding Governance: Policy, Networks, Governance, Reflexivity and Accountability, Buckingham, Open University Press.

SCHARPF F.W. (1997), Games Real Actors Play. Actor-Centred Institutionalism in Policy Research, Boulder, Westview Press.

SCOTT W.R. (1987), Organizations. Rational, Natural and Open Systems, Englewood Cliffs, NJ, PrenticeHall.

SHARPE L.J. (1979), Decentralist trends in Western Democracies, London, SAGE Publications.

SHARPE L.J. (1993), The Rise of Meso Government in Europe, London, SAGE Publications.

SMIDT M. de (1990), De Randstad in internationaal perspectief, Stedelijke Netwerken, Werkstukken 21. Utrecht.

SMITH B.C. (1985), Decentralization. The Territorial dimension of the State, London, George Allen and Unwin. 
STOKER G. (1996), «Introduction», in KING D. and STOKER G. (eds.) (1996), Rethinking Local Democracy, London, Macmillan Press, pp. 1-27.

TÖRNQVIST G. (1980), Arbetslivets Geografi. Personliga synpunkter pa utvecklingsdrag efter 1950, ERUrapport 3. Stockholm, Industridepartement.

TÖRNQVIST G. (1983), «Creativity and the renewal of regional life», in BUTTIMER A. (ed.), Creativity and Context, Lund Studies in Geography, Series B. Human Geography, 50, pp. 91-112.

VALLER D., WOOD A. and NORTH P. (2000), «Local governance and local business interests: a critical review», Progress in Human Geography, 24, 3, pp. 409-428.

VAN GUNSTEREN H.R. (1976), The Quest for Control. A critique of the rational-central-rule approach in public affairs, London, John Wiley \& Sons.

WRR (1997), Grenzen aan verandering. De verhouding tussen reorganisatie en structuurprincipes van het binnenlands bestuur, Wetenschappelijke Raad voor het Regeringsbeleid. Den Haag, Sdu Uitgever.

\section{ABSTRACTS}

The paper examines the character of multipurpose territorial government and explores the meaning of frequent calls for more flexibility in the structures and functioning of local and regional governments. The paper elaborates on a number of starting points of debate concerned with the shift from territorial government to territorial governance. Configurations of territorial governance are operating within a broader and more diverse range of factors at both local and regional levels. These include non-elected agencies of the state, private businesses, voluntary organisations, the mass media, and EU institutions. Situations of diffused accountability arise from continuing interactions between network partners, exchange of resources and negotiation of shared purposes, and they constrain the field of democratic accountability. Importantly, one of the key characteristics of the shift from government to governance is claimed to be increased flexibility and responsiveness, in both the functioning and the structure of territorial government. Finally, building on the foregoing, the paper emphasises the issue of public interest formation and aggregation, and the adverse impacts of the fragmentation on the integrative territorial competence of multipurpose governments. The critical assessment provided shows that the notion of flexibility appears to refer to the capability to react to unpredictable future developments by enlargement of management capacity through new steering and decisionmaking rules. Correspondingly, flexibility does not necessarily refer to changing the existing organisational structures of territorial self-government and administration but primarily to adaptations of their mode of functioning and, therefore, to increasing flexibility of rules and approaches.

Het artikel onderzoekt de aard van integraal territoriaal bestuur en gaat de betekenis na van de roep naar meer flexibiliteit in de structuren en het functioneren van lokale en regionale besturen. Het neemt een aantal vertrekpunten van de discussies over de verschuiving van territoriaal bestuur naar territoriale governance onder de loep. Configuraties van territoriale governance zijn werkzaam binnen een breder en losser verband van actoren op lokale en regionale niveaus zoals niet-verkozen overheidsorganen, privé ondernemingen, vrijwilligersorganisaties, massamedia of Europese instellingen. Voortdurende interacties tussen netwerkpartners, uitwisseling van hulpmiddelen en onderhandelingen over gedeelde doelstellingen leiden tot situaties van diffuse verantwoordelijkheid en beperken het veld van democratische aansprakelijkheid. Cruciaal is de bewering dat toenemende flexibiliteit en versneld reactievermogen zowel inzake het functioneren als inzake de structuur van territoriaal 
bestuur de sleutelkenmerken zijn van de verschuiving van bestuur naar governance. Voortbouwend hierop gaat het artikel tenslotte dieper in op het probleem hoe het algemeen belang totstandkomt en hoe fragmentatie de integrerende territoriale bevoegdheid van integrale besturen nadelig beïnvloedt. Uit deze kritische evaluatie blijkt dat de notie van flexibiliteit verwijst naar het vermogen om te reageren op onvoorspelbare ontwikkelingen door het verhogen van de beheerscapaciteit via alternatieve nieuwe regels voor sturing en besluitvorming. Flexibiliteit verwijst dus niet noodzakelijk naar een verandering van de bestaande organisatiestructuren van territoriaal zelfbestuur en administratie, maar in de eerste plaats naar aanpassingen van het functioneren daarvan en bijgevolg naar toenemende flexibiliteit in regels en manieren van aanpak.

INDEX

Keywords: multipurpose government, flexibility, reforms of territorial government Trefwoorden integraal bestuur, flexibiliteit, hervormingen van territoriaal bestuur

\section{AUTHOR}

\section{PETR DOSTÁL}

Department of Social Geography and Regional Development, Faculty of Science, Charles University, Prague, Czech Republik, dostal@natur.cuni.cz 